Metasediment - gneiss relationships north of the study area

A helicopter reconnaissance east of Suiterqut (16 km north of Qingussâq) revealed a contact of fundamentally different character to that described. Here a broad zone at the contact consists of a network of granitoid veins and sheets cutting the sediments and appears to pass transitionally into homogeneous granitoid rocks. A short investigation in Uvkusigssat $\left(71^{\circ} 03^{\prime} \mathrm{N} ; 51^{\circ} 53^{\prime} \mathrm{W}\right)$ revealed that the granitoid rocks are deformed, and lithologically very similar to the post $D_{1}$ tourmaline bearing pegmatites described in the study area.

Acknowledgements. Logistical support was provided by $N$. V. Ussing with Bjarne Eriksen as skipper, and by a Greenlandair Charter jet-ranger helicopter on charter to Greenex a/s Mârmorilik.

\title{
References
}

Henderson, G. \& Pulvertaft, T. C. R. 1967: The stratigraphy and structure of the Precambrian rocks of the Umanak area, West Greenland. Meddr dansk geol. Foren. 17, 1-20.

Rosenkrantz, A., Noe-Nygaard, A., Gry, H., Munck, S. \& Lauersen, D. 1942: A geological reconnaissance of the southern part of the Svartenhuk peninsula, West Greenland. Meddr Grønland 135(3), 72 pp.

Steenstrup, K. J. V. 1883: Bidrag til Kjendskab til de geognostiske og geographiske Forhold i en Del af Nord-Grønland. Meddr Grønland 4, 173-255.

Geologisch Instituut der Universiteit van Amsterdam,

130, Nieuwe Prinsengracht, $1018 \mathrm{VZ}$ Amsterdam, The Netherlands.

\section{Reconnaissance study of uranium and fluorine contents of stream and lake waters, West Greenland}

\section{Agnete Steenfelt and Else Dam}

The present study forms part of a current investigation on the applicability of geochemical methods in mineral exploration in Greenland.

The sampling programme of 1981 comprised three parts:

(1) A helicopter supported, low density, regional sampling (1 sample/30 $\mathrm{km}^{2}$ ) of stream water and stream sediment in the area covered by map sheet 66 V.2, south-east of Søndre Strømfjord. A total of 207 water samples was obtained. 
Table 2. Analytical methods

\begin{tabular}{llll}
\hline & Firm & Type of instrument & $\begin{array}{l}\text { Lower } \\
\text { detection limit }\end{array}$ \\
\hline $\mathrm{pH}$ & $\begin{array}{l}\text { Radiometer } \\
\text { Radiometer }\end{array}$ & $\begin{array}{l}\text { pH-meter } 29 \\
\text { combined glass/calomel } \\
\text { electrode GK 2401 C } \\
\text { conductivity meter }\end{array}$ & $1 \mu \mathrm{ohm}^{-1}$ \\
$\mathrm{U}$ & WPA & $\begin{array}{l}\text { UA-3 Uranium analyser } \\
\text { Specific ion-meter PHM 53 } \\
\text { Combined fluoride electrode } \\
\text { buffer: TISAB III }\end{array}$ & $\mathbf{5 ~ p p b}$ \\
\hline
\end{tabular}

(2) Detailed sampling within a $20 \mathrm{~km}^{2}$ area of lake and stream water (71 samples) from a camp at $66^{\circ} 49^{\prime} \mathrm{N}, 25^{\circ} 37^{\prime} \mathrm{W}, 25 \mathrm{~km}$ south-west of Søndre Strømfjord.

(3) Reconnaissance sampling, by boat, along the southern part of the west coast of Greenland. The aim of this reconnaissance was to obtain information on the character of the drainage systems and on the availability of sample media (water, stream sediment, aquatic moss) for geochemical exploration. A total of 195 water samples was collected. In addition, rust zones and areas of known mineralisation along the coast were sampled.

The present report deals with a study of the water samples only. The following topics will be treated:

(1) The variation in $\mathrm{pH}$, conductivity, $\mathrm{F}$ and $\mathrm{U}$ contents.

(2) The effect of filtering and acidifying stream water samples on the results of the measurements.

In addition, the logistic conditions for low density sampling of drainage systems will be shortly discussed.

\section{Sampling and analysis}

The water samples were collected in $100 \mathrm{ml}$ polyethylene bottles. A number of samples was filtered on site through a $0.45 \mu \mathrm{m}$ millipore filter mounted on a $50 \mathrm{ml}$ piston pump. Measurements of $\mathrm{pH}$, conductivity and $\mathrm{U}$ and $\mathrm{F}$ contents were carried out, as specified in Table 2, partly at a field laboratory at Søndre Strømfjord and partly at the Survey in Copenhagen.

Fluorine analyses were for the first time included as part of the routine analytical programme. Investigations in East Greenland have shown that the fluorine concentrations in stream water had a significant variation related to the bedrock lithology, high $F$ concentrations being found in streams that intersect fault zones with hydrothermal mineralisation (Steenfelt \& Kunzendorf, 1979). 

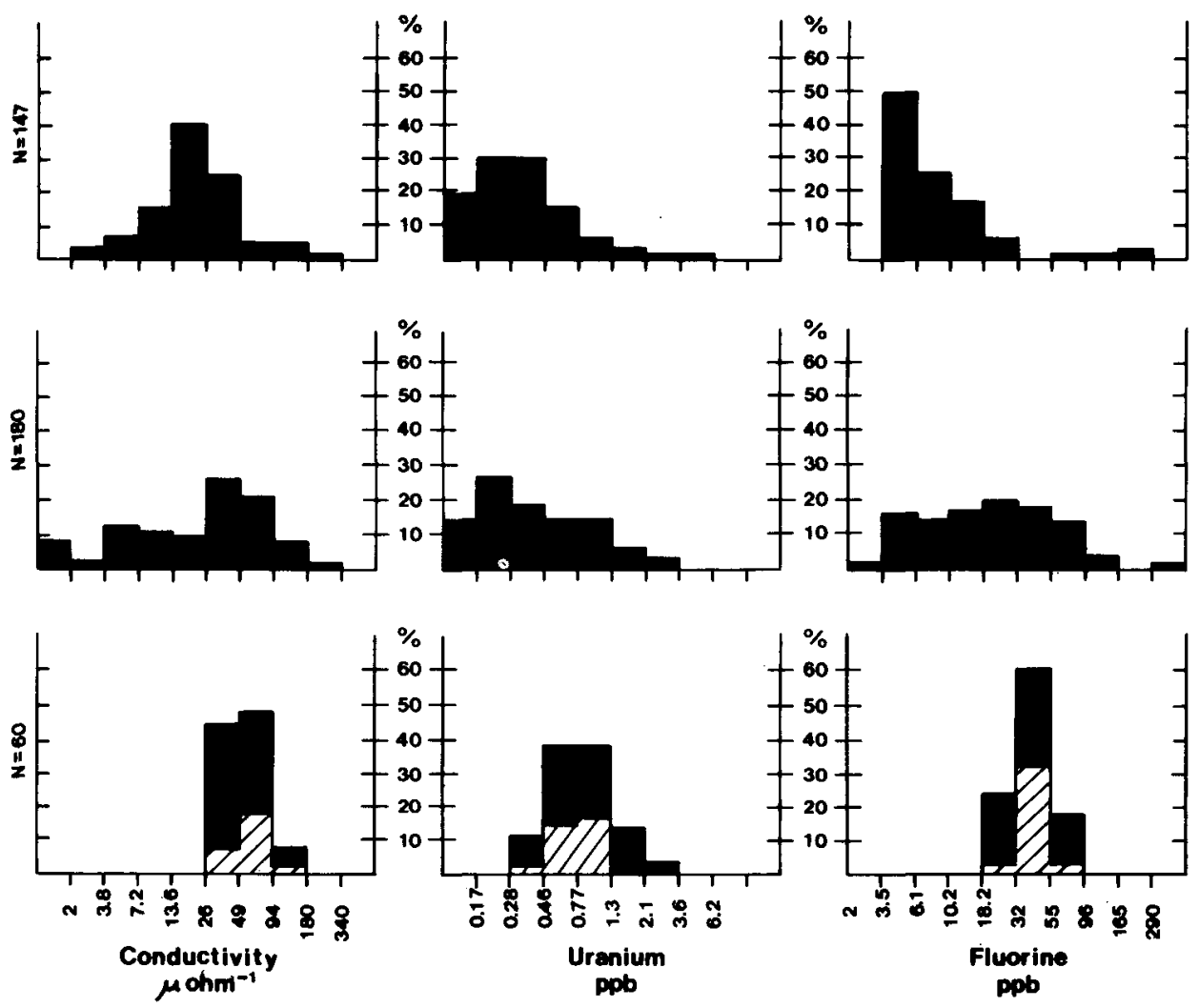

Fig. 7. The frequency distribution of conductivity, uranium and fluorine concentration in stream water (black) and lake water (hatched) in three areas in West Greenland. Ningimaneq is a local sampling area $\left(20 \mathrm{~km}^{2}\right.$ in size within map sheet 66 V.2). The class intervals are logarithmic.

\section{Variation in $p H$, conductivity, $U$ and $F$ concentrations}

The variation in conductivity and $\mathrm{U}$ and $\mathrm{F}$ concentrations is shown by the histograms of fig. 7. The $\mathrm{pH}$ values varied from 6.5 to 7.8 .

The reproducibility of the measurements was tested by sampling a number of streams twice at the same time, and was $\pm 0.2 \mu \mathrm{ohm}^{-1}$ for the conductivity measurements, \pm 0.2 for $\mathrm{pH}, \pm 20$ per cent for $U$ concentrations $( \pm 0.05 \mathrm{ppb}$ for samples with $U<0.25 \mathrm{ppb})$ and \pm 10 per cent for $F$ concentrations $( \pm 2.5 \mathrm{ppb}$ for samples with $F<25 \mathrm{ppb}$ ) (all values quoted at the 95 per cent level of confidence).

To test the local variation in the measured parametres, detailed sampling was carried out on a hilly plateau of $c .20 \mathrm{~km}^{2}$ with numerous small lakes. The variation of the analytical results was small (fig. $7 \mathrm{c}$ ), and is not much greater than the reproducibility of the measurements at one locality. The data illustrated in fig. $7 \mathrm{c}$ also show that the lake waters do not differ significantly from the stream waters with respect to the properties measured here. 


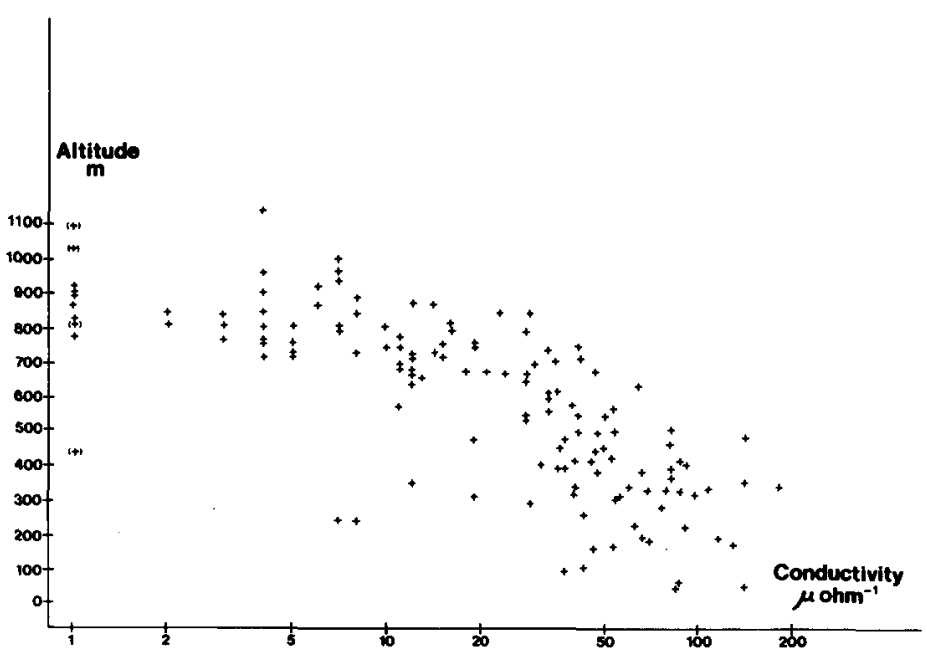

Fig. 8a. The relation between the conductivity of the stream water and the elevation of the sample site in map sheet 66 V.2. Samples with conductivity less than $1 \mu \mathrm{ohm}^{-1}$ are shown in brackets at the position for conductivity equal to $1 \mu \mathrm{ohm}^{-1}$.

The stream waters from the regional sample collection within map sheet 66 V.2 (fig. 7b) show a much greater variation in conductivity and $U$ and $F$ concentrations than the local variation illustrated in fig. $7 \mathrm{c}$. This variation can largely be explained as an effect of the topography, since there is a clear inverse correlation between the parametres measured and the elevation of the sample site. This is illustrated for the conductivity in fig. 8a, but applies also for the $\mathrm{U}$ and $\mathrm{F}$ concentrations which are strongly correlated with the conductivity. For $\mathrm{F}$ this is illustrated in fig. $8 \mathrm{~b}$.

A study in East Greenland has shown that the conductivity of the stream water is related to its total content of dissolved components (Asmund \& Steenfelt, 1976). The elevated areas in map sheet $66 \mathrm{~V} .2$ are covered by ice and snow, and the water of the streams draining these areas is predominantly runoff meltwater with very little material in solution and therefore with very low conductivity. At lower altitudes, particularly in the valleys, there is a significant contribution of ground water to the streams and consequently a much higher conductivity.

The amount of dissolved material in the streams, and thereby the conductivity of the water, also changes in time, because of variations with time in the runoff. Steenfelt \& Kunzendorf (1979) showed that, over a period of three field seasons, the conductivity and $U$ concentrations decreased in rainy periods and increased in dry periods. In consequence of these correlations, $\mathrm{U}$ and $\mathrm{F}$ concentrations in stream waters should always be evaluated in relation to the corresponding conductivity values.

Most of the area covered by map sheet 66 V.2 is underlain by Archaean granulite facies gneisses and, in the northwestern part, by the retrograded equivalents of these which belong to the Nagssugtoqidian mobile belt (Escher et al., 1970). The geochemistry of the gneisses is not well known but they probably have low and more or less uniform $U$ and $F$ contents. This is probably the main reason why the effect of the topography on the $U$ and $F$ concentration in the stream waters is so clearly displayed.

An interesting geochemical anomaly within map sheet 66 V.2 is the Sarfartôq carbonatite 
Fig. 8b. The relation between the concentration of $F$ and the conductivity of stream water in map sheet 66 V.2. Samples with conductivity less than $1 \mu \mathrm{ohm}^{-1}$ are not shown. Two samples collected within the Sarfartôq carbonatite complex are marked S.

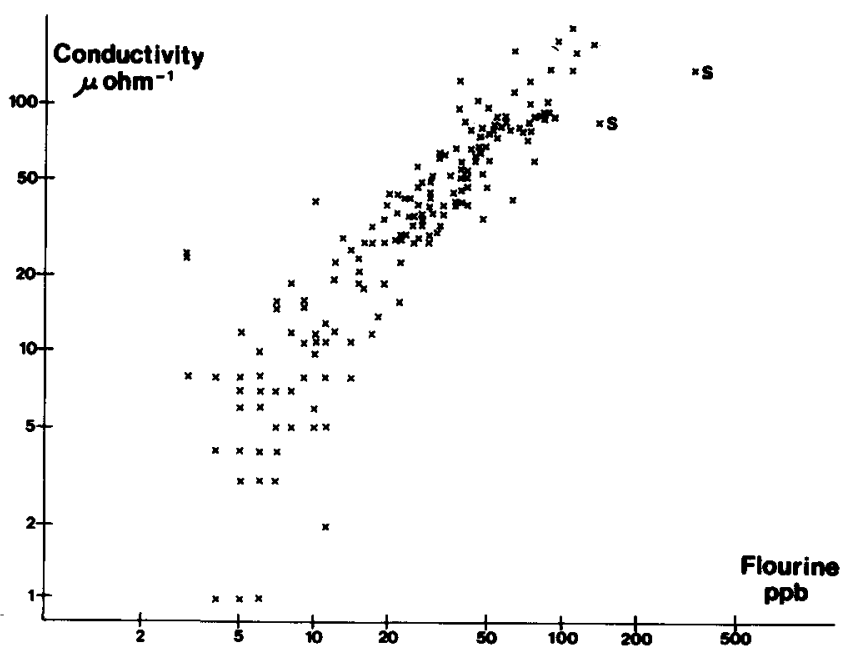

complex (Secher \& Larsen, 1980). Two water samples collected within this complex are enriched in $F$ relative to the conductivity (fig. $8 \mathrm{~b}$ ).

In the reconnaissance sampling along the coast of West and South Greenland most of the samples have very low F contents, but a few stand out (fig. 9). These represent two areas in which mineralised joints and fractures were known to exist, the Lilianminen hydrothermal copper mineralisation at Kobberminebugt and a granite on the west coast of Lichtenau Fjord with $U$ mineralised joints and fractures. The $U$ content of the stream waters draining this granite is also high (2-3 ppb). It appears that the $\mathrm{F}$ analyses in the present study support the experience from East Greenland concerning $F$ enrichment in streams draining areas of hydrothermal mineralisation.

\section{Effect of filtration and acidification of water samples}

Some streams, especially those fed by glaciers, contain much particulate material in suspension. This might be suspected to influence the analytical results, and filtering might therefore be necessary. To test the effect of filtration on the measurements, 25 pairs of samples were collected, and one of each pair filtered on site. No significant differences, however, were found for any of the properties measured ( $\mathrm{pH}$, conductivity, $\mathrm{U}$ and $\mathrm{F}$ concentrations) between the filtered and the non-filtered samples.

The concentration of dissolved metal ions in a water sample may undergo changes during storage in the bottles as a result of changes in $\mathrm{Eh}$ and $\mathrm{pH}$ caused by escape of $\mathrm{CO}_{2}$ or $\mathrm{O}_{2}$, and of adsorption of metals onto the wall of the sample container. Therefore it is often advocated to add a minor amount of acid to the samples, in order to ensure that the metals are kept in solution.

An investigation of the effects of acidifying the water samples on the measured $U$ concentrations was commenced in 1980 by B. L. Olesen, A. Armour-Brown and the first author. Two drops of $1 \mathrm{~N} \mathrm{HNO}_{3}$ were added to duplicates of 74 water samples collected in 


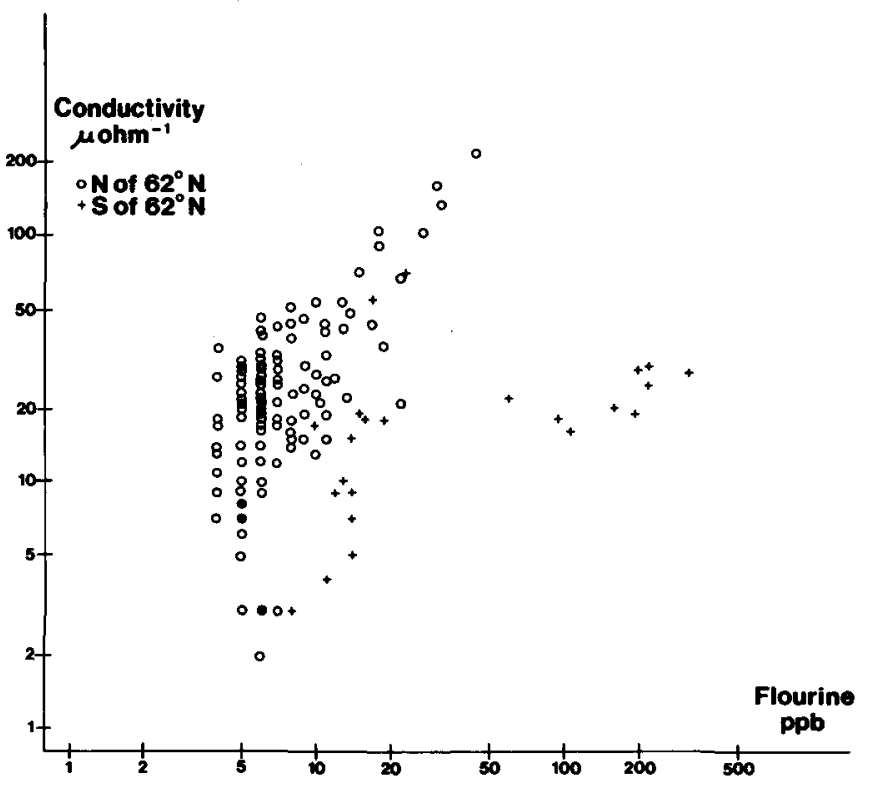

Fig. 9. The relation between the concentration of $F$ and the conductivity of stream water samples from reconnaissance collections in West (circles) and South Greenland (crosses).

South Greenland. The analyses of these acidified samples typically showed 30-70 per cent higher $\mathrm{U}$ concentrations than the corresponding non-acidified duplicates. The reason for this is not clear. One explanation that has been considered is that the acid might dissolve particles in suspension, or bring into solution ions adsorbed onto particulate matter. A few samples collected in 1981 were filtered before acidification. These samples show the same apparent increase in $\mathrm{U}$ concentration and hence do not support the explanation suggested above.

\section{Logistics}

The sampling of map sheet 66 V.2 was not completed, but enough experience was gained to estimate the helicopter support required for this type of low-density drainage sampling (stream sediment as well as stream water). One 1:250000 map sheet $\left(c .10000 \mathrm{~km}^{2}\right)$ with 300 sample sites would require 45 hours of helicopter (Bell 206 B) flying time, spent in 10 sampling days of 8-10 hours duty, over a period of 15 working days. The remaining days cover the pilot's off-days, preparation for sampling, drying and packing of samples, and plotting of the sample locality map.

During these 15 days it is possible to analyse all water samples for $\mathrm{pH}$, conductivity, and $\mathrm{U}$ and $\mathrm{F}$ concentrations in a field laboratory. 


\title{
Summary
}

The regional variation in conductivity, $\mathrm{U}$ and $\mathrm{F}$ concentrations in stream water is greater than the variation in a local sampling area. The variation within map sheet $66 \mathrm{~V} .2(10000$ $\mathrm{km}^{2}$ ) reflects predominantly topographical differences. This is mainly due to the chemical uniformity of the bedrock in the area.

The Sarfartôq carbonatite complex and two occurences of hydrothermal mineralisation in South Greenland are distinguished by high $\mathrm{F}$ concentrations in the stream water, relative to waters with the same conductivity.

Filtration of the stream water samples does not affect the measured conductivity, $U$ or $F$ concentrations. Addition of acid causes an increase in the measured $U$ concentrations.

\section{References}

Asmund, G. \& Steenfelt, A. 1976: Uranium analysis of stream water, East Greenland. J. geochem. Explor. 5(3), 374-380.

Escher, A., Escher, J. \& Watterson, J. 1970: The Nagssugtoqidian boundary and the deformation of the Kângamiut dyke swarm in the Søndre Strømfjord area. Rapp. Grønlands geol. Unders. 28, 21-23.

Secher, K. \& Larsen, L. M. 1980: Geology and mineralogy of the Sarfartôq carbonatite complex, southern West Greenland. Lithos 13, 199-212.

Steenfelt, A. \& Kunzendorf, H. 1979: Geochemical methods in uranium exploration in northern East Greenland. In Watterson, J. R. \& Theobald, P. K. (edit.) Geochemical Exploration 1978. Association of Exploration Geochemists.

\section{Detailed ground magnetic survey in the central part of the Sarfartôq carbonatite complex, southern West Greenland}

\author{
K. Secher and L. Thorning
}

\section{Introduction}

A detailed ground magnetic survey was carried out by the authors and Egon Hansen, electronics technician, during the spring of 1981 in the central part of the Sarfartôq carbonatite complex near Søndre Strømfjord. It was important for the survey that there was continuity of measurements over the whole area, and as most of the area was covered by swamp in the bottom of the valley Arnangarnqup kûa, it was most convenient to make the survey when the surface was frozen. 